Rozmowa z profesorem Matíasem Martínezem i profesorem Michaelem Scheffelem o aktualnych tendencjach w badaniach nad narracją

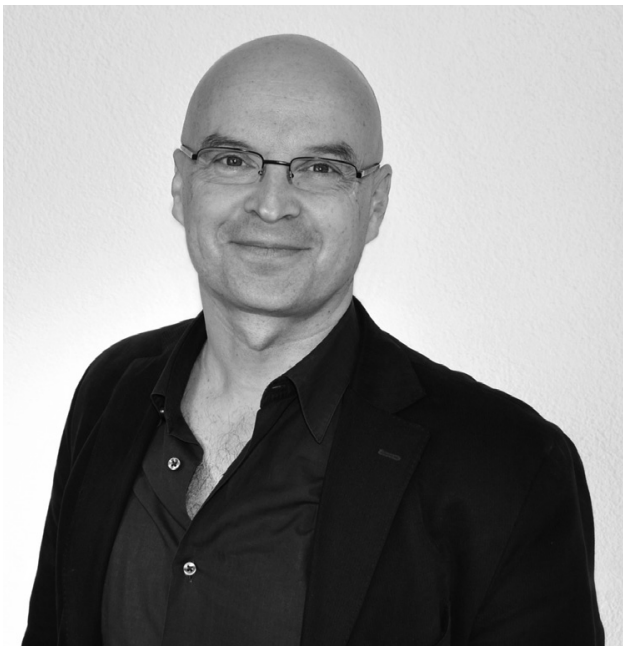

Matías Martínez

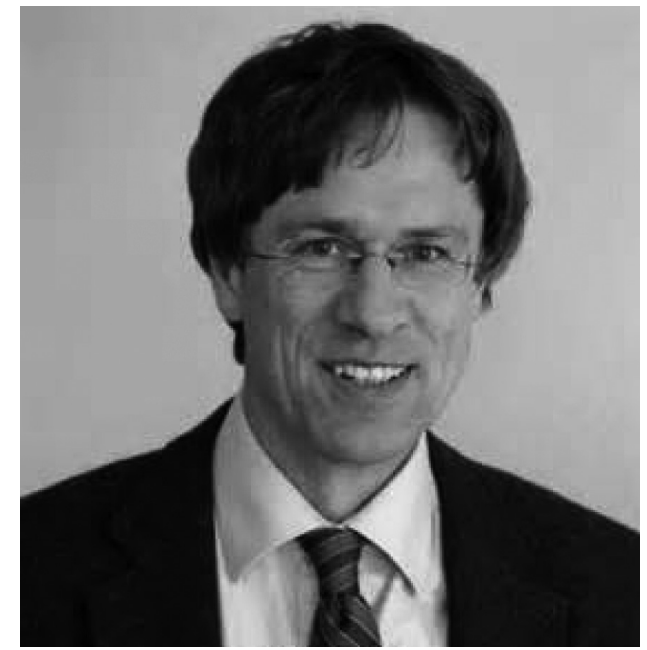

Michael Scheffel

\title{
Narratologia otwarta
}

Litteraria Copernicana: Panowie Profesorowie, późnym latem ubiegłego roku ukazało się dziewiąte wydanie Panów wspólnego dzieła, Wprowadzenia do teorii narracji. W ciągu trzynastu lat od ukazania się pierwszego wydania książka stała się jednym z podstawowych germanistycznych (i nie tylko) kompendiów, zyskała zatem status, który zawsze niesie ze sobą niebezpieczeństwo posągowego zastygnięcia. Najwidoczniej postanowili Panowie stawić czoło temu zagrożeniu, jako że kolejne wydanie zostało nie tylko zaktualizowane pod względem bibliograficznym, ale i rozszerzone o nowe zagadnienia. Co się zmieniło w stosunku do poprzednich wydań?
Matías Martínez: Oprócz korekt stylistycznych oraz aktualizacji i uzupełnień bibliograficznych dodaliśmy nowe rozdziały o narratologicznych pojęciach postaci i przestrzeni, a więc o dwóch fundamentalnych kategoriach świata przedstawionego w tekstach narracyjnych. W narratologii lat 90 . postać nie odgrywała zbyt wielkiej roli, ale w ostatnich latach pojawily się nowe badania na temat tego pojęcia, których wyniki chcieliśmy zaprezentować. Mniej więcej to samo dotyczy pojęcia przestrzeni o tyle, o ile aktualne badania nad tą kategorią wychodzą poza Łotmanowskie pojęcie sjużetu, które zresztą uwzględniliśmy już na samym początku.

Poza tym podczas pracy nad nową wersją książki mogliśmy z pewną dozą satys- 
fakcji stwierdzić, że pewne ważne trendy w międzynarodowej narratologii minionego dziesięciolecia są obecne w naszym Wprowadzeniu już od pierwszego wydania, mimo że w czasie, kiedy pracowaliśmy nad jego pierwszą wersją, to jest od połowy do końca lat 90 . XX wieku, bynajmniej nie dominowały one w dyskusji badawczej i zdecydowanie pozostawały niedostrzeżone przez porównywalne kompendia literaturoznawcze, czy to w języku niemieckim, czy też francuskim lub angielskim. Dotyczy to zarówno ujęcia literaturoznawczej narratologii z punktu widzenia psychologii kognitywnej (z pojęciami schematu, skryptu itp.), jak i otwarcia się samej narratologii na lingwistykę konwersacji (narracja w życiu codziennym), teorię historiografii i antropologię, częściowo także na naratologię historyczną. Poza tym w owym czasie $\mathrm{w}$ niemieckiej narratologii wciąż dominowała tradycja niemieckojęzyczna (Franz K. Stanzel, Eberhard Lämmert), podczas gdy my uwzględniliśmy także wyniki badań m.in. Dorrit Cohn, Gérarda Genettéa, Félixa Martíneza-Bonatiego czy Haydena White’a, które dopiero później zyskały szersze uznanie także w literaturoznawstwie niemieckim.

$\mathrm{Z}$ drugiej strony jest oczywiste, że w ramach naszego wprowadzenia mogliśmy przedstawić zaledwie ogólny zarys licznych cząstkowych obszarów badań narratologicznych, które zwłaszcza w minionym dziesięcioleciu uległy szczególnemu zróżnicowaniu; $w$ tej sytuacji wiele zagadnień szczegółowych musiało zostać pominiętych.

LC: Czy Panów własne zainteresowania badawcze miały także wpływ na wybór nowego materiału? I jakimi kryteriami kierowali się Panowie poza tym? Czy chodziło tylko o przedstawienie możliwie najszerszego przekroju, czy też chcieli Panowie zaznaczyć także ewentualne zmiany w narratologicznych tendencjach?
Scheffel: Od własnych zainteresowań i przekonań z pewnością nigdy nie można zupełnie się oderwać, ale przynajmniej staraliśmy się możliwie jak najobszerniej zdać sprawę z nowych dążności rozwojowych w narratologii. Kierując się tym zamiarem, gruntownie przeredagowaliśmy i zaktualizowaliśmy wskazówki do literatury przedmiotu; poza tym zwłaszcza nowy rozdział o postaci i poszerzone wywody na temat aspektu przestrzeni odzwierciedlają aktualne tendencje badań narratologicznych.

Martínez: Na potrzeby literaturoznawczego wprowadzenia do analizy tekstów narracyjnych, które powinno nadawać się do szerokiego zastosowania, uwzględnienie aktualniejszych trendów międzynarodowych badań nad narracją nie jest kwestią pierwszorzędną, trendy te bowiem skupiają się raczej wokół specyficznych kontekstów narracji, a nie wokół ogólnych cech tekstów narracyjnych. Zasygnalizowaliśmy wprawdzie niektóre kontekstopochodne aspekty narracji, niemniej większość używanej dzisiaj terminologii analitycznej pochodzi nadal z okresu tak zwanej 'klasycznej' fazy narratologii, trwającej od lat 60. do 80. minionego stulecia. W ostatnich latach w narratologii chodziło raczej o zastosowanie tych terminów do określonych korpusów tekstów albo do pragmatyki funkcjonowania tekstu w określonych środowiskach. $\mathrm{Z}$ tego też powodu podstawowa koncepcja naszej książki pozostaje ważna mimo pojawienia się nowszych tendencji rozwojowych.

LC: Czy 'poklasyczną' fazę narratologii można jednolicie opisać? Czy też nie jest to jeden 'zwrot', tylko wiele, i to niezależnych od siebie - oczywiście o ile samo pojęcie zwrotu jest tu uzasadnione, o co też przy okazji pytam. 
Scheffel: Ogólnie uznaje się, że przeciwstawienie narratologii 'klasycznej' i 'postklasycznej' opiera się na daleko idącym uproszczeniu, czy też wyostrzeniu kontrastu. Już wczesny Roland Barthes (weźmy na przykład jego słynny Wstęp do analizy strukturalnej opowiadań (Introduction a l'analyse structurale des récits, 1966), ale także częściowo formalizm rosyjski oraz strukturalizm praski i rosyjski nie interesowały się tylko tekstami literackimi i możliwie dokładnym opisem ich właściwości, tylko najrozmaitszymi rodzajami narracji, uwzględniając przy tym wciąż na nowo związki między kulturą a literaturą, czy też kulturą a narracją w szczególności. To właśnie owo szerokie spojrzenie na wszystkie rodzaje opowiadań i ich konteksty ma się na myśli, mówiąc dzisiaj o narratologii 'postklasycznej' spod znaku 'zwrotu narracyjnego' w naukach o kulturze. Poszczególne warianty podejść kognitywistycznych czy zorientowanych na kontekst reprezentują zupełnie odmienne zainteresowania i metody, innymi słowy, obszar badań narratologicznych, zresztą w coraz większym stopniu interdyscyplinarnych, transgenerycznych i intermedialnych, poszerzył się tymczasem $\mathrm{w}$ stopniu prawie uniemożliwiającym jego ogarnięcie. Przy całej różnorodności z rozwoju tego bezspornie wynika, iż ta forma narratologii, która definiuje się jako systematyczne badanie narracji $w$ jej rozmaitych przejawach, w rosnącym stopniu umiejscawia się poza granicami tradycyjnych przedmiotów akademickich jako swojego rodzaju dyscyplina przekrojowa. Dla adekwatnego oddania tego biegu wypadków, a zarazem dla stworzenia centralnego i postrzegalnego w skali międzynarodowej forum dla związanych z nim dyskusji powołaliśmy właśnie do życia przy wuppertalskim „Centrum Badań nad Narracją” (ZEF) czasopismo „DIEGESIS”, będące interdyscyplinarnym elektronicznym periodykiem narratologicznym (diegesis.uni-wuppertal.de).
Martínez: Z punktu widzenia tak zwanej narratologii 'poklasycznej' fazy badań nad narracją określane mianem 'protoklasycznej' (zwłaszcza formalizm rosyjski drugiego i trzeciego dziesięciolecia XX w.) i 'klasycznej' (strukturalizm francuski i amerykański low structuralism lat 60.-80. XX w.) nabierają z perspektywy czasu myląco jednolitego charakteru. Ów rzekomo nowy, przekraczający granice pluralizm metodologiczny i tematyczny, charakterystyczny dla narratologii postklasycznej, zawsze był częścią badań nad narracją. Począwszy od eksploracji kina przez formalistów rosyjskich i stworzenia zalążków narratologii historycznej przez niemieckie badania morfologiczne $\mathrm{w}$ okresie Republiki Weimarskiej, poprzez Morfologię bajki Proppa i etnologiczną teorię mitu Lévi-Straussa, aż po Mitologie Barthes'a czy przedstawioną przez Umberto Eco analizę powieści o Jamesie Bondzie, studia nad nieliterackimi formami narracji od zawsze stanowily istotną część składową badań narratologicznych.

Niemniej jednak nowsze tendencje oczywiście też się pojawiły. Widzę tu przede wszystkim:

- narratologię postkolonialną, klasową i genderową: te często politycznie umotywowane podejścia analizują ideologiczne funkcje określonych technik narracyjnych;

- narratologię kognitywną: chodzi w niej o psychologiczno-empiryczną analizę warunków rozumienia tekstów narracyjnych;

- narratologię medialną i intermedialną: próbują one ująć specyfikę, ale i ponadgatunkowe cechy wspólne narracji w poszczególnych mediach;

- narratologię historyczną: repertuar pojęciowy narratologii klasycznej powstawał przeważnie w odniesieniu do nowoczesnej literatury narracyjnej. Narratologia historyczna bada roz- 
wój historyczny określonych technik narracyjnych;

- narratologię komputerową: w ramach Digital Humanities w ostatnich latach pojawiają się (co prawda nieliczne) próby uprawiania ilościowej analizy tekstów narracyjnych na podstawie literackich baz danych i informatycznych algorytmów.

Podejścia te bardzo się od siebie różnią metodami, przedmiotami badań i interesami poznawczymi. Wszystkie zajmują się wprawdzie zjawiskiem narracji i posługują się (po części także krytycznie) zwyczajową terminologią narratologiczną, poza tym jednak nie dostrzegam łączących je podobieństw.

LC: To oczywiste, że historyczne fazy są konstrukcjami o nieostrych brzegach, i że w zależności od punktu widzenia bardziej koncentrujemy się na wyrazistych sednach albo na przepuszczalnych granicach. Czy jednak narratologii nie dotknęła także potrzeba samookreślenia, która na przełomie tysiącleci opanowała filologiczne umysły i która wyraźnie stała pod znakiem zmiany paradygmatu? Z jednej strony literaturoznawcy obawiali się, że wymyka im się obiekt badań (czemu dali wyraz $\mathrm{w}$ dyskusji prowadzonej na łamach "Jahrbuch der Schillergesellschaft" od 1997 roku), z drugiej strony witano $z$ entuzjazmem powstanie literaturoznawstwa zorientowanego kulturoznawczo - ogółem przyszłość naszej dyscypliny rozważana była pod kątem dylematu „refilologizacja albo rozszerzenie”. Nawiązując do tak określonych stanowisk, chciałem Panów spytać, czy narratologia jest dziś jeszcze dyscypliną, której (jak to sugeruje także rozkład materiału we Wprowadzeniu) nie jedynym, ale jednak uprzywilejowanym obiektem pozostają teksty literackie?

Scheffel: Jak już to obaj zaznaczyliśmy, także w narratologii jak najbardziej miało miejsce coś $\mathrm{w}$ rodzaju zasadniczego rozszerzenia pola badawczego w imię 'zwrotu kulturowego. Tu jednak trzeba rozróżniać z jednej strony zainteresowania i koncepcje teoretyczne, z drugiej zaś strony analityczną praktykę. W swych koncepcjach teoretycznych liczne odmiany współczesnej narratologii zajmują się zdecydowanie nie tylko tekstami (literackimi). Jeśli jednak chodzi o badania praktyczne, które są przecież prowadzone przez narratologów $\mathrm{z}$ reguły wykształconych w pierwszym rzędzie jako filolodzy, to ich przedmiotem nadal są w większości teksty literackie, które de facto stanowią, jak Pan mówi, „uprzywilejowany obiekt” zainteresowań. To spostrzeżenie w mniejszym stopniu stosuje się jednak do wspomnianych przez pana Martíneza podejść kognitywnych i intermedialnych. Niezależnie od tego rośnie liczba prac zajmujących się np. specjalnie narracją $\mathrm{w}$ filmie i/lub mediach cyfrowych, - z których na przykład Narratologia filmu (2011), opublikowana przez Markusa Kuhna w renomowanej serii wydawniczej „Narratologia”, prezentuje model teorii narracji wykorzystujący $\mathrm{w}$ istotnym zakresie pojęcia i sposób modelowania przedstawiony w naszym Wprowadzeniu. To, że ów aparat pojęciowy da się zastosować także poza tekstami literackimi i filmami (np. w dyskursie prawniczym, medycznym, psychoanalitycznym czy też $w$ naukach przyrodniczych), demonstrują np. artykuly zawarte $\mathrm{w}$ wydanym przez Christiana Kleina i Matíasa Martíneza zbiorze poświęconym narracjom o rzeczywistości (Wirklichkeitserzählungen, 2011).

Martínez: To, że studia narratologiczne prowadzone przez literaturoznawców tak jak dawniej preferują narracje literackie, nie powinno przecież dziwić. Ale oprócz wcale nie tak rzadkich opracowań pisanych przez literaturoznawców na temat nieliterackich form i obszarów narracji, mamy dziś do czy-

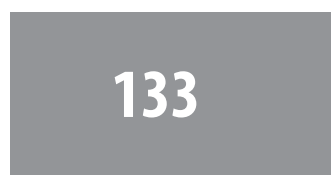


nienia w obrębie filmoznawstwa, lingwistyki konwersacji, psychologii, psychoterapii, teologii i innych dyscyplin z bardzo kompetentnymi pod względem narratologicznym analizami, pisanymi przez naukowców będących ekspertami w tych poszczególnych dziedzinach i $\mathrm{z}$ tej pozycji próbujących adekwatnie uchwycić właśnie nie-literacką specyfikę badanych przez siebie tekstów. Niemniej jednak to literaturoznawcza narratologia wypracowała szczególnie zróżnicowane słownictwo z zakresu analizy tekstu, które może się przydać innym dyscyplinom. Dlatego raczej nie jest rzeczą przypadku, że powstałe $\mathrm{w}$ ostatnich latach najważniejsze interdyscyplinarne międzynarodowe ośrodki narratologiczne (w Columbus/ /Ohio, Hamburgu, Paryżu czy Wuppertalu) są wszystkie założone i prowadzone przez literaturoznawców.

Dla mnie osobiście narratologia od zawsze była interdyscyplinarnym projektem badawczym, otwierającym dostęp do najprzeróżniejszych fenomenów kulturowych. Różnorodność jej zastosowania, bynajmniej nie tożsama z metodologiczną dowolnością, jest przedmiotem mojej niezmiennej fascynacji. Narratologia umożliwia każdemu, kto bystrym okiem obserwuje naszą kulturę, dostrzec narracyjne podstawy strukturyzowania i generowania znaczeń, czy to w relacjach z meczów piłki nożnej, ogłoszeniach reklamowych, legendach miejskich czy gazetowych reportażach.

LC: Poszerzenie pola widzenia na pewno wzbogaca wszystkie dyscypliny uczestniczące $\mathrm{w}$ tym procesie: literaturoznawcza narratologia może dzięki podejściom kognitywnym czy antropologicznym lepiej postrzegać swoje własne podstawy, a badanie dyskursów potocznych czy specjalistycznych zyskuje nowe wymiary dzięki uwzględnieniu aspektów narracyjnych. Mówiąc o uprzywilejowanej pozycji narracji artystycznej (obok literackiej zalicza się do niej naturalnie także filmowa), zakładałem, że nie jest ona uzasadniona tylko tradycją dyscypliny, która ją bada, ale także faktem, że owe sposoby narracji często posługują się bardziej złożonymi technikami (np. wielość perspektyw, struktura szkatułkowa, niewiarygodność instancji narracyjnej), a przez to stawiają większe wyzwania badawcze. Czy też może nie doceniam pod tym względem potencjału dyskursów niefikcjonalnych?

Martínez: To raczej prawda, że artystyczna narracja wytworzyła szczególnie złożone formy wyrazu. Ale właściwie dlaczego? Wśród powodów należałoby wymienić:

- po pierwsze, specyficzną, związaną $\mathrm{z}$ treningiem szkolno-akademickim, wolnym czasem i wielokrotną lekturą recepcję tekstów estetycznych, która jest $\mathrm{w}$ stanie zrozumieć także skomplikowane konstrukcje;

- po drugie, wolność mowy fikcjonalnej (czyli nierzeczywistej komunikacji między wyimaginowanymi partnerami) od empirycznych ograniczeń narzuconych mowie odnoszącej się do faktów, która to wolność pozwala na tworzenie także 'nienaturalnych' form narracji;

- po trzecie wreszcie, wysoki prestiż, jaki w toku literackiej ewolucji zyskały innowacyjne formy w porównaniu ze skonwencjonalizowaną narracją.

$\mathrm{Z}$ drugiej strony trzeba wziąć pod uwagę, że mnogość pragmatycznych kontekstów narracji niefikcjonalnej nie jest czymś wobec niej zewnętrznym, tylko wywiera także wpływ na jej formę. Tak na przykład $\mathrm{w}$ lingwistyce konwersacji istnieje cały szereg typowych dla niej kategorii do analizy narracji potocznych, autobiograficznych czy posttraumatycznych, z których korzyści odnieść mogą także narratolodzy zorientowani literaturoznawczo. 
Scheffel: Do odpowiedzi pana Martíneza mogę dodać tylko jedno (co zresztą już zostało w niej zasygnalizowane): w odróżnieniu od wielu potocznych form narracji, narracja fikcjonalna stanowi formę mowy „Zwolnionej z obowiązków”, i to właśnie ta jej właściwość w niemałym stopniu umożliwia uczynienie z narracji literacko-fikcjonalnej pola do eksperymentów w obrębie danej kultury, swojego rodzaju „narracyjnego laboratorium", jak to już w latach 60 . XX wieku ujął francuski autor Michel Butor. Jeśli zaś przyjmiemy założenie, że modele narracji i modele działania pozostają wobec siebie w stosunku wzajemnej zależności, istnienie takiego „laboratorium” ma znaczenie także dla rozwoju kultury.

LC: Uprzedzili Panowie moje następne pytanie, które miało dotyczyć jeszcze jednej cechy uprawniającej narrację artystyczną do uprzywilejowanego traktowania, a mianowicie jej odpragmatyzowanego charakteru, który umożliwia obserwację form narracyjnych w postaci niejako 'czystej', 'uwolnionej' od pozaestetycznych uwikłań. W tym punkcie słusznie podnoszą Panowie kwestię historycznych i społecznych uwarunkowań oraz pewnej sztuczności tego statusu, który nieraz bywał absolutyzowany przez koncepcje metodologiczne skoncentrowane na formie. Jednak owa absolutyzacja była swego czasu reakcją na krytykowaną już przez rosyjskich formalistów instrumentalizację literatury jako nośnika 'przesłań, stanowiła zatem istotny krok w kierunku unaukowienia literaturoznawstwa czy wręcz zyskania przez nie tożsamości. Czy sądzą Panowie, że nasza dyscyplina nie potrzebuje już takiego zawężenia?

Scheffel: Koncentracja na aspekcie formy estetycznej, typowa czy to dla teoretycznych założeń formalizmu rosyjskiego i części strukturalizmu, czy to dla części powojen- nej literatury (np. francuskiej nouveau roman i nouveau nouveau roman, ale także w utworach pisarzy niemieckojęzycznych, takich jak Helmut Heißenbüttel, Ernst Jandl, Ernst Gomringer, wczesny Peter Handke i in.), jest czy też była dzieckiem swojego czasu i należy ją rozumieć także jako reakcję na instrumentalizację, czyli właściwie nadużycie (także) literatury przez wielkie ideologie i systemy totalitarne XX wieku. Dzisiejsze literaturoznawstwo nie potrzebuje już takiej, jak to Pan ująl, „absolutyzacji”, aby uzasadnić swoją tożsamość. Z drugiej strony niektóre $\mathrm{z}$ aktualnych tendencji idących $\mathrm{w}$ kierunku całkowitego zniesienia granic pojęciowych między literaturą a nie-literaturą, typowych dla literaturoznawstwa postrzegającego siebie jako ogólną wiedzę o kulturze, wydają mi się jednak także niebezpieczne. Aby ująć to może w sposób uproszczony, ale za to dobitny: Tak się składa, że istota dyscypliny zwącej się literaturoznawstwem zasadza się na tym, że istnieje przedmiot zwany literaturą. Dlatego choć literaturoznawstwo powinno jak najbardziej zajmować się związkami, takimi jak - żeby wymienić tylko najpopularniejsze - „literatura a kultura”, „literatura a media”, „literatura a pamięć”, i przez to odzwierciedlać najrozmaitsze oblicza stosunku tekstu do kontekstu, nie powinno jednak tracić zupełnie z oczu pytania o differentia specifica literatury. Moim zdaniem podobny postulat odnosi się także do granicy czy stosunku między narracją literacką a nieliteracką, czy (i tu już kryje się problem, który zawsze będzie wart teoretycznych wysiłków) narracją fikcjonalną a niefikcjonalną.

Martínez: Ja jestem nastawiony zasadniczo przychylnie do nowego otwarcia się literaturoznawstwa na inne dyscypliny (choć może nie we wszystkich jego konkretnych formach wyrazu) i, inaczej niż pan Scheffel, dostrzegam $\mathrm{w}$ nim raczej szansę niż zagrożenie. Nawiązując do Pańskiej wzmianki o formali-

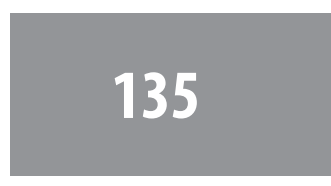


stach rosyjskich, chciałbym tu odwrócić tok argumentacji. To prawda, formaliści zwracali się przeciwko zaniedbywaniu przez literaturoznawstwo tego, co specyficznie literackie. Ale 'literackość' dostrzegali (przede wszystkim Roman Jakobson, ale także Tynianow $\mathrm{i}$ inni) nie tylko w literaturze rozumianej jako zbiór tekstów, w których dominuje zasada artystyczna czy funkcja poetycka, ale także w tekstach nieliterackich, jak na przykład reklama. Nie chodziło im o zawężenie zakresu przedmiotowego przez literaturoznawstwo skupione na formie, tylko o koncentrację na aspektach artystycznego kształtowania tekstów. Tak ukierunkowane spojrzenie nie ogranicza się do tekstów literackich, tylko wręcz przeciwnie - otwiera dostęp do tekstów nieliterackich. Badanie semantyki form tak literackich jak nieliterackich, a także krytyczna ocena jej funkcji to program badawczy, który wydaje mi się szczególnie istotny dla zainteresowanego kulturoznawczo literaturoznawstwa w obliczu nowej rzeczywistości, opisywanej przez niektórych jako konglomerat wirtualnych symulakrów.

Ponadto trzeba trzeźwo stwierdzić, że społeczne rozpowszechnienie i oddziaływanie literatury w naszej kulturze wyraźnie słabnie na korzyść innych mediów i form wyrazu artystycznego. Można się z tym zgadzać lub nie, chodzi jednak o zmianę, która w najbliższych dekadach da się odczuć coraz silniej i prawdopodobnie wystawi na ciężką próbę tradycyjną legitymizację uniwersyteckich kierunków filologicznych.

LC: Niezależnie od tego, z jaką dozą sceptycyzmu śledzi się nowsze tendencje rozwojowe w literaturoznawstwie, trzeba zgodzić się z tym, że kulturoznawcze otwarcie naszej dyscypliny odzwierciedla zmiany, które zaszły w obrębie jej przedmiotu: pielęgnowanie idei czystości gatunku i sztuki dla sztuki ustępuje tu celebracji najrozmaitszych gatunków zmąconych. Dopóki refleksja filo- logiczna koncentruje się na aspektach formalno-technicznych, wybór jej przedmiotu jest być może sprawą drugorzędną. Co więcej, uwzględnienie tekstów nieartystycznych może być pomocne dla systematycznego ujęcia ewentualnych nieadekwatnych funkcjonalizacji tekstów artystycznych. Czy sądzą jednak Panowie, że w kontekście omawianych tendencji można jeszcze podzielić zastosowania sztuk narracyjnych na stosowne (przyjemność estetyczna, interpretacja naukowa) i niestosowne (interpretacyjne idiosynkrazje, ilustracja zagadnień pochodzących $\mathrm{z}$ innych nauk, propagowanie idei politycznych)? I jeśli tak, to czy narratologia może wnieść specyficzny wkład do tego zróżnicowania?

Martínez: Tak, rzeczywiście uważam, że narratologiczne badanie fenomenów kulturowych może być ważne w sensie politycznym i kulturowokrytycznym. Nawet jeśli ten jego aspekt nie stał w centrum badań narratologicznych ostatnich dziesięcioleci, da się wymienić parę dobrych przykładów myślę tu o Rolandzie Barcie i jego analizach kultury popularnej i codziennej w Narratologiach. Albo o Christianie Salmonie i jego badaniach nad rolą narracyjnych technik (uwodzenia) w gospodarce, reklamie i polityce ostatnich lat, zawartych w jego książce Storytelling. Opowieści mogą bowiem nie tylko informować, bawić i relacjonować, ale także manipulować. Główny rezultat tych i podobnych badań polega na odkryciu, że użycie struktur narracyjnych wytwarza argumentacyjną wartość dodaną, albo sens kulturowy, który nie jest wyrażony otwarcie (a przez to rozpoznawalny), tylko sugerowany podprogowo. Narratologia może odsłonić retoryczny charakter takich technik narracyjnych.

LC: Czy za manipulację (dokonywaną na przedmiocie badań i zarazem, choć nieko- 
niecznie, na odbiorcy) można uznać także dokonywane implicite przeklasyfikowanie tegoż przedmiotu? Chodzi mi o takie użycie tekstu, które przypisuje mu jednoznaczną wypowiedź o rzeczywistości. Przychodzą mi tu na myśl przede wszystkim praktyki totalitarnych ideologów, narzucających literackim tekstom polityczne odczytania, ale ten sposób użycia literatury występuje także w mniej drastycznej formie: kiedy na przykład literatura przywoływana jest jako ilustracja określonych 'przypadków', jak we Freudowskiej lekturze Hamleta $\mathrm{w}$ Interpretacji marzeń sennych, albo kiedy stosuje się teksty literackie terapeutycznie, jako nośniki 'mądrości życiowych'. Łatwo nasuwa się wtedy zarzut redukcji (a co za tym idzie, założenie obligatoryjnej wielowymiarowości obiektów artystycznych). Interesuje mnie specjalnie, czy taka redukcja dałaby się uchwycić także za pomocą kategorii narratologicznych, innymi słowy, czy interpretacji, która w taki sposób instrumentalizuje teksty, dałoby się udowodnić przemilczanie określonych narracyjnych niuansów?

Scheffel: Jeśli dobrze rozumiem Pana pytanie, to taką 'redukcję da się - może nie zasadniczo, ale w pewnych przypadkach - jak najbardziej ująć czy określić za pomocą kategorii narratologicznych. W wielu bowiem przypadkach (dotyczy to np. wielu literackich lektur Freuda, choćby jego odczytanie Piaskuna E.T.A. Hoffmanna) interpretacja skupia się tylko na samej 'treści' opowiadanej historii, zaniedbując wymiar formy estetycznej, a tym samym, w przypadku tekstów narracyjnych, ostatecznie także sposób przedstawienia opowiadanych treści (którego podstawową cechą może być specyficzna, być może ambiwalentna perspektywizacja opowiadanych zdarzeń). Albo inaczej: $\mathrm{w}$ takich wypadkach następuje redukcja złożoności opowiadania poprzez uprzywi- lejowanie plaszczyzny 'historii' kosztem płaszczyzny 'dyskursu' (zdarza się to m.in. także w zorientowanych treściowo odczytaniach utworów Kafki, charakteryzujących się przecież wysokim stopniem złożoności).

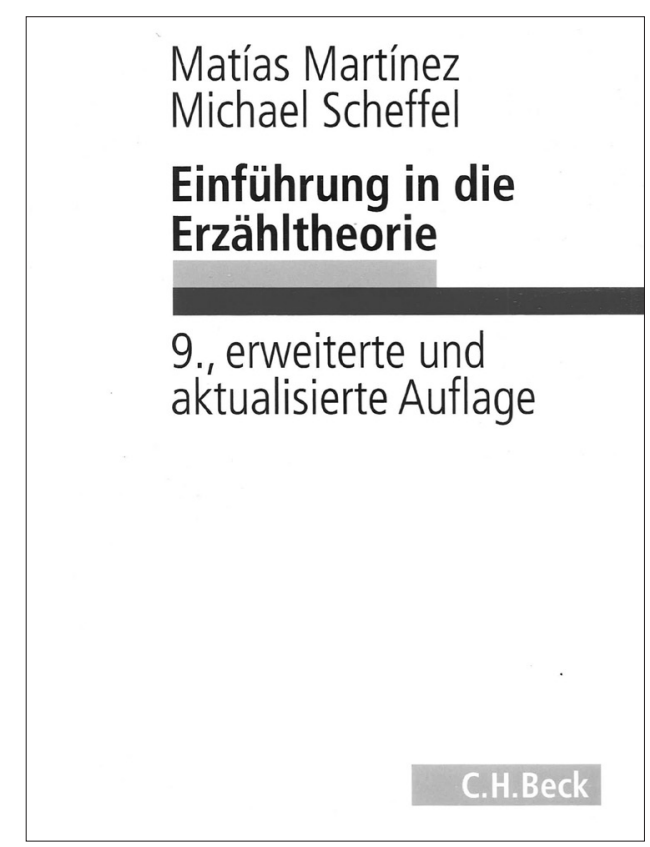

Martínez: Przychylam się do odpowiedzi pana Scheffela, chciałbym jednak poddać pod rozwagę, że założenie „obligatoryjnej wielowymiarowości obiektów artystycznych" sugeruje normatywną koncepcje (dobrej, bo wieloznacznej) literatury, niemającą zastosowania na przykład do literatury tendencyjnej i popularnej. Czy z tego powodu teksty te nie są literackie? Jeśli ujmiemy orzecznik 'literacki' opisowo, będzie nam jak najbardziej wolno przypisać takim tekstom (przynajmniej w intencji - wszystko bowiem może być przedmiotem odmiennego zrozumienia czy nieporozumienia) jednoznaczne znaczenia, nie wyrzucając ich przy tym poza obręb literatury. Ale i dla nich narratologia oferuje adekwatne środki analityczne, odnoszące się mniej do aspektów dyskursu, a bardziej do obecnej w tych tekstach historii. Porównawcza analiza intrygi

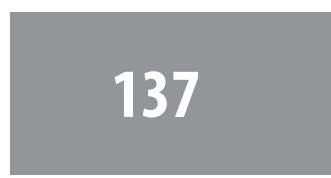


pozwala na przykład uznać utwory narracyjne kultury popularnej za literaturę schematyczną, której znaczenie da się wyprowadzić z jej seryjnego charakteru, polegającego na powtarzaniu (z wariacjami) określonego wzoru intrygi. Tutaj porównawcza analiza narratologiczna mogłaby odsłonić właśnie zredukowany semantycznie charakter takich utworów, który pozostałby nierozpoznany, gdyby analizować dzieło tylko jako obiekt indywidualny.

LC: Jednym z wielu pożytków naszej rozmowy jest dla mnie odkrycie, jak bardzo przywiązany jestem do - z pewnością zasługującego na relatywizację - poglądu, że analiza literatury artystycznej mimo wszystko stanowi 'królewską drogę' teorii narracji. Moje ostatnie pytanie dotyczyć będzie jednak znowu dyskursów niefikcjonalnych. Interesuje mnie mianowicie, czy fakt, że zostały one 'odkryte' przez narratologię doczekał się jakiegoś odzewu z ich strony. Taki odzew mógłby polegać na przykład na tym, że zdania o rzeczywistości używają terminów narratologicznych lub wykazują wzmożoną tendencje do autorefleksji. Na przykład w Polsce w ostatnich latach pojęcie narracji wyraźnie zaznaczyło swoją obecność w debatach politycznych, kiedy to konkurujące ze sobą partie wytykały sobie nawzajem wolę narzucenia społeczeństwu 'swoich' narracji (czyli sposobów przedstawiania pewnych historycznych czy aktualnych wydarzeń). Czy zaobserwowali Panowie podobne zjawiska?

Martínez: Pojęcia narracji i narratywu stały się w ostatnich latach modne i bywają używane $\mathrm{w}$ mowie potocznej (niestety, także w dyskursach akademickich) w sensie o wiele bardziej rozmytym i szerokim niż ten właściwy dla narratologii.

Często jednak takie użycie pojęć jak najbardziej pasuje do aktualnych fenome- nów. Jak to wykazal np. Christian Salmon w Storytelling, zwłaszcza od lat 90. XX wieku używa się typowych dla narracji technik przedstawieniowych jako narzędzi retorycznych w celach manipulacji. Działania takie podejmowane są przykładowo $\mathrm{w}$ okresie kampanii wyborczych przez spin doktorów, którzy przyporządkowują 'swoim' kandydatom i partiom najbardziej pasujące, bo obiecujące największy sukces historie, albo w reklamie, która przedstawia produkty, już nie opierając się na ich rzekomych szczególnych cechach, tylko jako części określonej marki związanej ze szczególną historią.

W Niemczech przykładem nowej narracji historycznej o okresie nazistowskim wydaje mi się w ostatnich latach wzmożone zainteresowanie opinii publicznej niemieckimi ofiarami II wojny światowej. Ta narracja z pewnością nie ma stworzyć alternatywy dla narracji dotychczas dominującej, akcentującej przede wszystkim ofiary żydowskie. Niemniej buduje się jednak inną historię, $\mathrm{z}$ innym rozłożeniem akcentów prezentacji przeszłości.

Podobne zjawiska zachodzą teraz we Francji czy Holandii, gdzie przedmiotem badań i dyskusji staje się nie tylko ruch oporu, ale także kolaboracja z niemieckim okupantem.

Czy to dobrze, czy źle, nie należy tu do tematu. Tak czy owak, także w przypadku historii niefikcjonalnych „opowiadać” znaczy zawsze i nieodwołalnie konstruować opowiadany materiał poprzez wybór, przedstawienie i kombinację informacji na podstawie określonych kryteriów. Każde wydarzenie może być opowiedziane na nieskończoną ilość sposobów. Czasami odbywa się to według najlepszej wiedzy i w zgodzie z sumieniem narratora, czasami zaś w zamiarze manipulacji.

Scheffel: Mogę się tylko przyłączyć do opinii pana Martíneza i podkreślić ze swej strony, 
że szczególnie termin „narracyjny” stał się modnym pojęciem, które spotkamy wszędzie - nie tylko w nauce i kulturalnych działach czasopism. Dalszą ilustracją tej tendencji jest nowa książka Albrechta Koschorke Prawda i zmyślenie, która próbuje stworzyć projekt ogólnej teorii narracji z perspektywy kulturoznawczej i która poza tym zawiera liczne przykłady politycznej i niekiedy zarazem manipulacyjnej funkcji tak zwanych 'narratywów'.

Ścisłość związków między narracjami a pamięcią kulturową wykazał zresztą już jakiś czas temu Henry Rousso, francuski historyk ze szkoły Annales, w swojej - arcyciekawej także pod względem metodologicznym - książce Syndrom Vichy na przykładzie podejścia społeczeństwa francuskiego do własnej najnowszej przeszłości.

LC: Czy sądzą Panowie, że ta kariera pojęcia narratywu jest rezultatem wejścia $\mathrm{w}$ obieg masowy określonych teorii - myślę tu przede wszystkim o koncepcjach Haydena White'a? I czy należy powitać tę tendencję życzliwie (wyjąwszy wypadki nieadekwatnego stosowania terminów), na przykład jako oznakę rosnącej gotowości do zdystansowania się od absolutnych roszczeń wszelkich narracji (łącznie $\mathrm{z}$ własnymi)? Albo przynajmniej jako dowód na to, że akademicka myśl teoretyczna nie cierpi na nadmierny hermetyzm?

Scheffel: Zasadniczo raczej rzadko da się stwierdzić z pewnością, dlaczego określone pojęcie czy koncepcja wchodzi w modę. W przypadku 'narratywu' czy 'narracji' (tak w liczbie pojedynczej jak w mnogiej) na pewno nie jest to związane tylko $\mathrm{z}$ nowym historyzmem, naukami historycznymi i Haydenem White'em jako wplywowym 'popularyzatorem'. Moim zdaniem ta tendencja jest znakiem czasu: $\mathrm{w}$ dobie kulturoznawczego rozszerzenia filologii pojęcie czy koncepcja narratywu spadly jak z nieba, to one bowiem właśnie pozwalają na operowanie ponad granicami gatunku, pojedynczego medium czy literatury (ba, w ogóle tekstu) - także dlatego, że w sytuacji przebrzmienia innych intelektualnych mód, takich jak dekonstrukcja - wspomnijmy choćby „różnię” (différance) czy „swobodny przeplyw znaczącego" jako wszechobecne w swoim czasie pojęcia - i teoria dyskursu à la Foucault (włącznie z pojęciem dyskursu właśnie), pojęcie narracji stało się, jak to teraz pisze np. Koschorke w swojej Ogólnej teorii narracji [taki podtytuł nosi Prawda i zmyślenie - T. W.], „jedną z najbardziej skutecznych transdyscyplinarnie i najbardziej chętnych do ekspansji kategorii literaturoznawczych". A ponieważ ta tendencja, jak się wydaje, jest zgodna z duchem czasu, odnajdziemy ją także w tym, co nazywa Pan „obiegiem masowym" - przy czym moim zdaniem nie da się dokładnie powiedzieć, kto tu na co reaguje (to znaczy nie wydaje mi się, aby droga wpływu była jednokierunkowa, raczej ma tu miejsce oddziaływanie wzajemne).

Ja sam patrzę na tak naszkicowany bieg wypadków ze swego rodzaju sceptycznym optymizmem. Jako narratologa cieszy mnie oczywiście, że termin narracji jest teraz en vogue, i że nasza praca i jej przedmiot $\mathrm{w}$ rosnącym stopniu zostają powszechnie dostrzeżone i naraz przesunęły się niejako z peryferii do centrum zainteresowania, także w obrębie nauki (o kulturze) i jej - aby użyć tutaj jednego $\mathrm{z}$ dawniejszych modnych pojęć - dyskursu. Wiążę z tym jednak tylko umiarkowaną nadzieję na pozytywny rozwój społeczny w zasygnalizowanej przez Pana postaci. Bowiem rozwój nie jest sprawą określonego sposobu mówienia a wspomniana przez Pana gotowość do zdystansowania się od własnych roszczeń do absolutu przywoływana jest chętnie po to, aby w pierwszym rzędzie zredukować czy zdemontować roszczenia nie własne, tylko innych. O tendencji, aby rosnący poziom

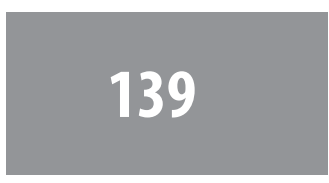


refleksji nad użyciem określonych 'narratywów' wykorzystywać do manipulacji, na przykład w dziedzinie gospodarki, przedsiębiorczości i kariery, jak i w walce o tak ważny dziś zasób, jakim jest uwaga, była już tu mowa. Niemniej jednak: omawiane tendencje z pewnością stwarzają szansę na (od) zyskanie przez naukową (a w szczególności literaturoznawczą) myśl badawczą i teoretyczną jakiejś formy powszechnej siły oddziaływania. Wykorzystajmy ją!

Martínez: Ciekawie byłoby prześledzić karierę pojęcia narracji $\mathrm{w}$ działach kulturalnych czasopism $\mathrm{w}$ ostatnich dziesięcioleciach i zastanowić się nad jego funkcjami w dyskursie publicznym: w związku z jakimi nazwiskami, teoriami i w odniesieniu do jakich treści był on używany, od kiedy i jak często? Osobiście przypuszczam, że ogłoszenie „końca wielkich narracji” (Jean-Pierre Faye i in.) miało tu jeszcze większy wplyw od Haydena White'a. A dlaczego pojęcie narracji stało się tak modne? Bo jest pomocne przy formułowaniu pozycji relatywistycznych, akcentujących zasadniczo ograniczone możliwości poznania, ale i działania politycznego. $\mathrm{W}$ takich wypadkach mamy do czynienia z polityczną i ideologiczną instrumentalizacją pojęcia. Ja jednak jestem zdania, że z nieuniknionego uznania konstrukcyjnego charakteru narracji bynajmniej nie musi wynikać radykalny relatywizm czy wszechogarniający fikcjonalizm.

LC: Serdecznie dziękuję Panom za rozmowę.

Rozmowę przeprowadził i przetłumaczył Tomasz Waszak
Profesor Matías Martínez i profesor Michael Scheffel wykładają najnowszą literaturę niemiecką i literaturoznawstwo ogólne na uniwersytecie w Wuppertalu. Obaj działają ponadto w prestiżowych gremiach literaturoznawczych: prof. Martínez przewodniczy wuppertalskiemu Centrum Badań nad Narracją, jest ponadto współredaktorem czasopisma "Diegesis" i serii wydawniczej „Narratologia”; prof. Scheffel współredaguje czasopismo "text + kritik" i serie wydawnicze "Allgemeine Literaturwissenschaft - Wuppertaler Schriften” oraz "Schriftenreihe Literaturwissenschaft". Najnowsze publikacje obu uczonych ściśle związane są z problematyką narratologiczną (Handbuch Erzählliteratur, red. Matías Martínez, Stuttgart 2011; Ambivalenz und Kohärenz. Untersuchungen zur narrativen Sinnbildung, red. Michael Scheffel z Julią Abel i Andreasem Blödornem, Trier 2009).

Wspólnym (ale nie jedynym: w roku 2010 w monachijskim wydawnictwie C.H. Beck ukazała się ich antologia klasyków teorii literatury) dziełem obu autorów jest, wydane niedawno po raz dziewiąty, wprowadzenie do teorii narracji (Einführung in die Erzähltheorie), cieszące się zasłużoną sławą wśród studentów i wykładowców wszystkich nauk filologicznych. Książka przedstawia w zintegrowany sposób najważniejsze koncepcje narratologiczne światowego literaturoznawstwa, wyposażając jej czytelnika w precyzyjny instrument do analizy i interpretacji utworów narracyjnych. 
Przestrzeń - 014

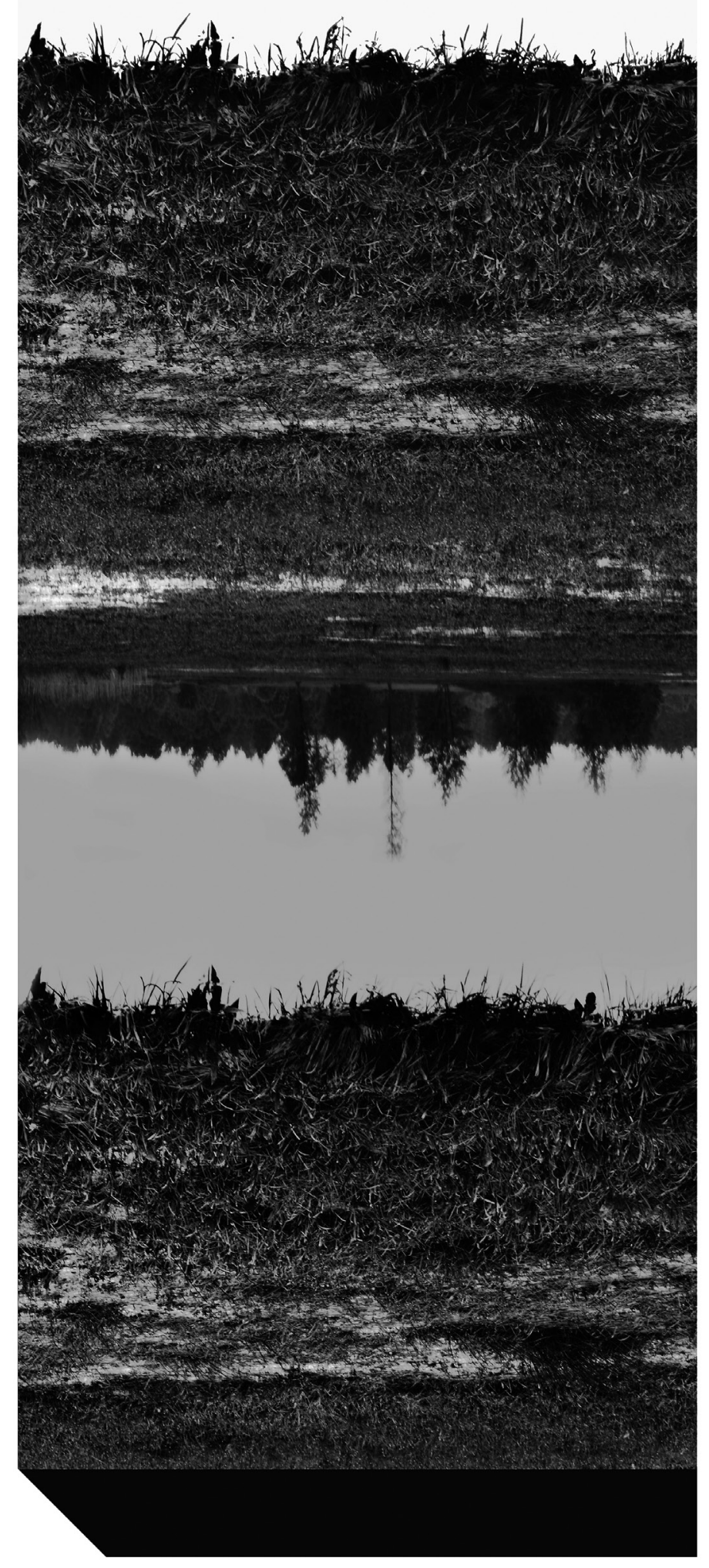

141

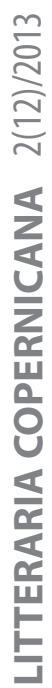

